\title{
Temperature versus substrate limitation of heterotrophic bacterioplankton production across trophic and temperature gradients in the East China Sea
}

\author{
Fuh-Kwo Shiah ${ }^{1, *}$, Kon-Kee Liu' ${ }^{2}$, Gwo-Ching Gong ${ }^{3}$ \\ ${ }^{1}$ Center of Oceanographic Research, National Taiwan University, Taipei, Taiwan, ROC \\ ${ }^{2}$ PO Box 23-13, Institute of Oceanography, National Taiwan University, Taipei, Taiwan, ROC \\ ${ }^{3}$ Department of Oceanography, National Taiwan Ocean University, Keelong, Taiwan, ROC
}

\begin{abstract}
A survey of heterotrophic bacterioplankton biomass $\left(B B_{;} 4\right.$ to $\left.64 \mathrm{mg} C \mathrm{~m}^{-3}\right)$, production (BP; 0.3 to $\left.14.7 \mathrm{mg} \mathrm{C} \mathrm{m}{ }^{-3} \mathrm{~d}^{-1}\right)$ and specific growth rates $\left(\mu ; 0.07\right.$ to $0.38 \mathrm{~d}^{-1}$ ) as well as concentrations of nitrate $\left(\mathrm{NO}_{3}^{-} ;<0.1\right.$ to $\left.15.6 \mu \mathrm{M}\right)$, particulate organic carbon ( $\mathrm{POC}_{;} 1$ to $60 \mu \mathrm{M}$ ) and chlorophyll a $(\mathrm{chl} ; 0.1$ to $4.0 \mathrm{mg} \mathrm{chl} \mathrm{m}^{-3}$ ) in the euphotic zone was conducted over the continental shelf of the East China Sea during the spring seasons of 1996 and 1997. Concentrations of $\mathrm{NO}_{3}^{-}$were high in the coastal areas and decreased offshore. In contrast, temperature $\left(12.2\right.$ to $\left.24.5^{\circ} \mathrm{C}\right)$ showed the opposite trend, with cool $\left(<20^{\circ} \mathrm{C}\right)$ and warm $\left(>20^{\circ} \mathrm{C}\right)$ waters distributed inside and outside the shelf edge, respectively. Inside the shelf edge, bacterial rate parameters ( $\mathrm{BP}$ and $\mu$ ) were positively correlated with temperature but showed no correlation with POC; values of $\mathrm{Q}_{10}$ for $\mathrm{BP}$ and $\mu$ were 2.7 and 3.3 respectively. From the shelf edge to the adjacent open ocean, bacterial rate parameters were positively correlated with POC only. These results imply that during the spring season, mechanisms controlling the spatial patterns of bacterial rate parameters over the shelf area are system-dependent. It is concluded here that temperature plays a more dominant role than substrate supply inside the shelf edge; however, from the shelf edge to the open ocean, the situation is reversed.
\end{abstract}

KEY WORDS: Bacterial production - Bacterial growth rates - Bottom-up control · Continental shelf Kuroshio $\cdot Q_{10}$

\section{INTRODUCTION}

Heterotrophic bacterioplankton are the major organisms responsible for the decomposition of dissolved organic compounds in the sea (Fuhrman 1992 and citations therein). The study of the mechanisms controlling bacterial growth has been an important issue within the perspectives of organic carbon cycling and planktonic trophodynamics. Bottom-up control (the variation of bacterial variables is controlled by the supply rates of dissolved organic substrate) and top-down control (the variation of bacterial variables is controlled by bacterivory and viral lysis) have all been proposed as

•E-mail:frank@odb03.gcc.ntu.edu.tw explanations for bacterial biomass and production variations in the field (see Ducklow \& Carlson 1992, Fuhrman 1992 for review). Recent studies have further demonstrated that the seasonal variations of bacterial rate parameters (production and specific growth rates) in eutrophic ecosystems (coastal, estuarine and brackish-water systems) might primarily be regulated by temperature, with substrate supply playing a lesser role (White et al. 1991, Ducklow \& Shiah 1993, Hoch \& Kirchman 1993, Berman et al. 1994, Griffith et al. 1994, Shiah \& Ducklow 1994a,b, 1995). However, the applicability of such hypotheses to the continental shelf ecosystem (mesotrophic to oligotrophic) is a significant question that has never been fully answered (Kemp 1994 and citations therein). 
The continental shelf is affected by processes derived from land and the open ocean simultaneously (Biscaye et al. 1994). The shelf receives a large amount of inorganic nutrients from river discharge and coastal erosion processes, which results in high standing stock and production rates of organic matter (Mantoura et al. 1991) fueling bacterial growth. The heterogeneous patterns of physical, chemical and biological variables across the shelf system (see below) may create a continuous trophic gradient for bacterial growth. A detailed examination of the spatial patterns of bacterial biomass and rate parameters in the shelf system may provide some insights into bacterial growth controlling mechanisms.

During spring, water properties in the shelf of the East China Sea (ECS) may be affected by 4 end members. Two of these serve as important sources of inorganic nutrients into the shelf area (Liu et al. 1992 and citations therein). They are the cold $\left(<15^{\circ} \mathrm{C}\right)$, low salinity $(<32.000$ psu) China Coastal Waters (CCW) and the cool $\left(<20^{\circ} \mathrm{C}\right)$, high salinity Kuroshio Subsurface Waters (KSW) which outcrops at the shelf edge all year round. The other 2 oligotrophic end members are the Kuroshio Waters (KW) and the Taiwan Strait Waters (TSW). Both the KW and TSW are characterized by high temperature $\left(22\right.$ to $\left.25^{\circ} \mathrm{C}\right)$ and high salinity (>34.000 psu), with their main streams flowing northward on the eastern and western sides of Taiwan, respectively. Primary production and chlorophyll concentrations in areas more affected by the KSW and CCW are about 2 - to 4 -fold higher than those observed in the KW and the TSW (Gong et al. 1996, Shiah et al. 1996).

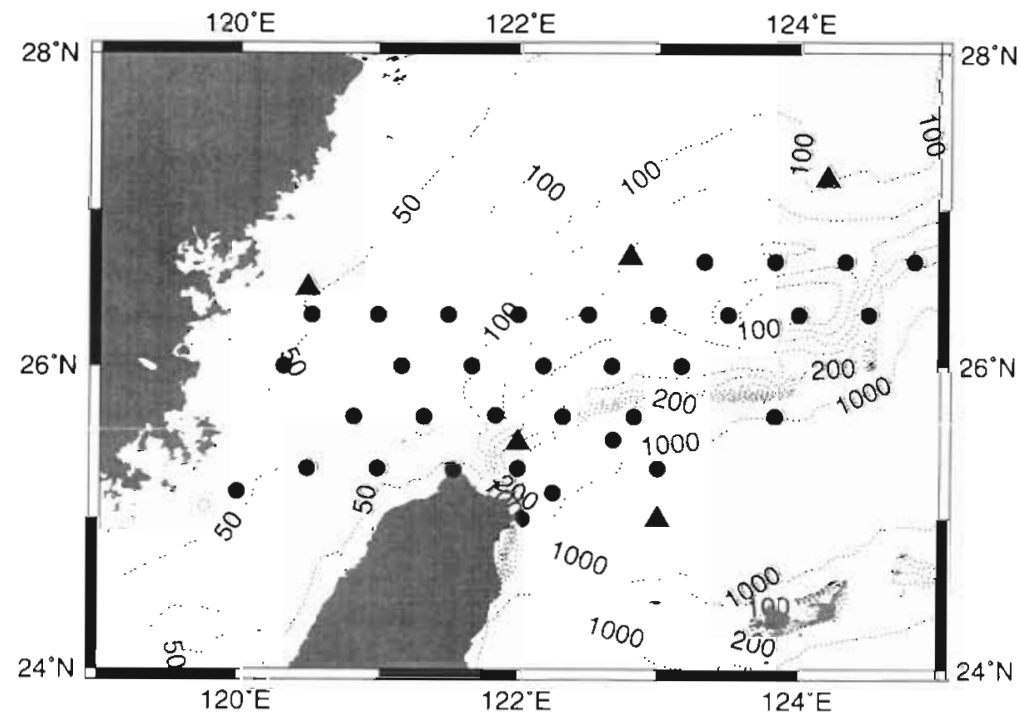

Fig. 1. Map of the southern East China Sea showing sampling stations for cruises 1996 (A) and 1997 (O). Dashed lines indicate the bottom depths in units of meters
Physical mixing processes among these 4 water masses make the continental shelf of the ECS a system characterized by strong gradients of inorganic nutrients and organic substrate, either in terms of concentrations or supply rates. In addition, the mixing of the cold (CCW \& KSW) and the warm water masses (KW \& TSW) may result in a broad range (ca 10 to $25^{\circ} \mathrm{C}$ ) of temperature change over the entire shelf area during spring. These variations provide an ideal opportunity to examine temperature and substrate supply effects on the bacterial rate parameters.

\section{MATERIALS AND METHODS}

Study area and sampling. Data were collected from 2 cruises conducted on the continental shelf of the southern ECS north of Taiwan (Fig. 1) during the spring seasons of 1996 (9 sampling stations) and 1997 (29 sampling stations). Seawater was collected from a SeaBird CTD-General Oceanic Rosette assembly with 201 Go-Flo bottles. Light intensity was measured with a light meter (QSP200L; Biospherical), while the depth of the euphotic zone was defined as $1 \%$ of the surface light level.

Bacterial biomass, production and growth rates. Bacterial abundance was determined by using the Acridine Orange Direct Count method (Hobbie et al. 1977). Samples fixed with glutaraldehyde (final conc., $1 \%$ ) were stained with acridine orange (final conc., $0.01 \%$ ) for 2 min before being filtered through $0.2 \mu \mathrm{m}$ polycarbonate filters prestained with an Irgalan black solution. Slides were enumerated by epifluorescence microscopy (Zeiss, Axioplan). Biomass was calculated using a carbon conversion factor of $2 \times 10^{-14} \mathrm{~g} \mathrm{cell}^{-1}$ (Lancelot \& Billen 1984). Bacterial production was estimated by the method of ${ }^{3} \mathrm{H}$-thymidine (Fuhrman \& Azam 1982) incorporation with a conversion factor of $1.18 \times 10^{18}$ cells mol thymidine ${ }^{-1}$ (Cho \& Azam 1988). Triplicate 30 to $40 \mathrm{ml}$ aliquots of water samples were incubated with ${ }^{3} \mathrm{H}$ [methyl]-thymidine (S. A., $6.7 \mathrm{Ci} \mathrm{mmol}^{-1}$; final conc, 20 nM) in clean polycarbonate tubes at in situ temperature. Reactions were stopped by adding formaldehyde (final conc., 1\%). The killed samples including time zero controls were filtered through $0.2 \mu \mathrm{m}$ cellulose nitrate filters. These filters were then rinsed 3 times each with ice cold $5 \%$ trichloroacetic acid and ice cold $80 \%$ ethyl alcohol sequentially. Scintillation cocktail $(6 \mathrm{ml}$; Ultima Gold, Packard) was added after the dried 
filters were dissolved completely in $0.5 \mathrm{ml}$ of ethyl acetate. Radioactivity was determined by liquid scintillation counting (Packard 1600). Bacterial (specific) growth rates were calculated by dividing the bacterial production by the bacterial biomass.

Particulate organic carbon and nitrogen concentrations. Water samples $(0.5$ to $1.0 \mathrm{l})$ for particulate organic carbon (POC) and nitrogen (PN) measurements were filtered through a $200 \mathrm{~mm}$ mesh to remove zooplankton. After filtration $(25 \mathrm{~mm} \mathrm{GF/F}$ filters; pumping pressure $<100 \mathrm{~mm} \mathrm{Hg}$ ), the samples were wrapped in aluminum foil and stored at $-4^{\circ} \mathrm{C}$. Both the filters and aluminum foils had been pre-combusted at $550^{\circ} \mathrm{C}$ for $1 \mathrm{~h}$ before these filtration processes. POC and $\mathrm{PN}$ concentrations were measured by a $\mathrm{CHN}$ analyzer (Fisons; NA1500) after samples had been dried and acid-fumed.

Chlorophyll $\boldsymbol{a}$ and nitrate concentrations. $\mathrm{Chl} a$ and nitrate concentrations were measured following the methods of Parsons et al. (1984). Water samples for nutrient analyses were subsampled with clean $100 \mathrm{ml}$ polypropylene bottles and frozen immediately with liquid nitrogen. Nitrate was analyzed with a selfdesigned flow injection analyzer (Gong et al. 1995) and was reduced to nitrite with a cadmium wire which was activated with a copper sulfate solution. For chl $a, 1$ to $2 \mathrm{l}$ of seawater were filtered through $25 \mathrm{~mm}$ Whatman $\mathrm{GF} / \mathrm{F}$ filters which were then immediately stored at $-20^{\circ} \mathrm{C}$. Back at the laboratory, the filters were ground in $10 \mathrm{ml} 90 \%$ acetone followed by extraction in a $4^{\circ} \mathrm{C}$ shaking incubator for $2 \mathrm{~h}$. After centrifugation at $1000 \mathrm{rpm}(200 \times \mathrm{g})$ for $5 \mathrm{~min}$, the concentrations of chlorophyll in the supernatant were measured on a Turner fluorometer (model 10-AU-005).

Data analyses. The euphotic zone integrated data set was generated by integrating measured variables over the euphotic zone by trapezoid method. Parametric methods including correlation and regression analyses were performed with the Macintosh software StaView ${ }^{\mathrm{TM}}$ II (Abacus Concepts, Inc.). The non-parametric (Spearman rank correlation) method in that software was used to double check the results derived from parametric analyses, especially for the data set with small sampling size (i.e the $<20^{\circ} \mathrm{C}$ data set; see below). Both methods yielded the same conclusion.

\section{RESULTS}

Data collected from the 1997 cruise (29 sampling stations) were used to describe the spatial patterns of the measured variables, while the 1996 data (9 sampling stations) were presented in the statistical analyses together with the 1997 data. The depth of the euphotic zone was about 30 to $40 \mathrm{~m}$ in the inner shelf but increased to about 65 to $70 \mathrm{~m}$ in the outer shelf. With only a few exceptions, the euphotic zone of each station was well mixed, as judged from the homogeneously distributed temperature and salinity profiles (Fig. 2A). The average temperature of the euphotic zone changed by more than $10^{\circ} \mathrm{C}$, with the cool (ca 12 to $22^{\circ} \mathrm{C}$ ) and warm ( $\mathrm{ca} 20$ to $24^{\circ} \mathrm{C}$ ) waters located at the inner shelf and outside the shelf edge, respectively (Fig. 3A). A warm water mass (TSW) with temperatures $>20^{\circ} \mathrm{C}$ was found west of Taiwan. This northward flowing TSW mixed with the CCW and the KW thereby creating a strong temperature gradient in the middle shelf area. Salinity was positively correlated with temperature in areas of $<20^{\circ} \mathrm{C}$ (Fig. 2A). More than half (21 out of the 38 ) of the sampling stations had similar salinity $(-34.500 \mathrm{psu})$, but temperature varied from 17.0 to $24.5^{\circ} \mathrm{C}$. This indicates that temperature is probably a more suitable index than salinity in exploring the magnitude of the mixing among water masses over the shelf. This is particularly true in distinguishing the upwelled KSW and the oligotrophic KW since both water masses were characterized by similar salinity but different temperature and distinct nitrate concentrations (see below).

Surface nitrate concentrations $\left(\mathrm{NO}_{3}^{-} ; 0.2\right.$ to $\left.15.1 \mu \mathrm{M}\right)$ and euphotic zone integrated nitrate concentrations (INO; 6 to $488 \mathrm{mmol} \mathrm{m}^{-2}$; Fig. $3 \mathrm{~B}$ ) were high in the inner shelf region, yet decreased offshore. Two INO anomalies separated by low INO $\left(<100 \mathrm{mmol} \mathrm{m}^{-2}\right)$ waters were observed around the shelf edge. One was located at the upwelling area off northeastern Taiwan with INO $>250 \mathrm{mmol} \mathrm{m}^{-2}$; the other (INO $>150 \mathrm{mmol}$ $\mathrm{m}^{-2}$ ) was situated at $26.3^{\circ} \mathrm{N}, 124.0^{\circ} \mathrm{E}$. Values of INO were negatively correlated with temperature (Fig. 2B) and salinity when anomalies ( 7 data) derived from the upwelling areas were excluded $(\mathrm{p}<0.01, \mathrm{n}=31)$.

Concentrations of particulate organic carbon ( $\mathrm{POC}$; 1.2 to $60.4 \mu \mathrm{M}$ ) and the integrated POC (IPOC; 230 to $1220 \mathrm{mmol} \mathrm{m}^{-2}$ ) varied respectively about 50- and 5fold over the study area (Table 1). In 1997, most of the high IPOC values (>400 $\mathrm{mmol} \mathrm{m}^{-2}$ ) were recorded in the middle shelf with intermediate temperatures (17 to $22^{\circ} \mathrm{C}$; Fig. $2 \mathrm{C}$ ). Values of IPOC in the inner and middle shelf seemed to be higher ( $>2,00 \mathrm{mmol} \mathrm{m} \mathrm{m}^{-2}$ ) than those in the outer shelf on the 1996 cruise. Chl a concentrations varied 40 -fold with values ranging from 0.1 to

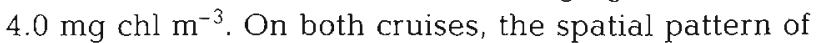
the integrated chl (Ichl; 6 to $122 \mathrm{mg} \mathrm{chl} \mathrm{m}^{-2}$ ) was almost identical to those of the IPOC. The correlation coefficient of Ichl versus IPOC was $>+0.90(n=38, p<0.01)$. IPOC was positively correlated with euphotic zone integrated particulate nitrogen (IPN; 627 to $135 \mathrm{mmol}$ $\mathrm{N} \mathrm{m}^{-2} ; \mathrm{n}=25, \mathrm{p}<0.01$ ); their relationship can be expressed as IPOC $=23+7.1( \pm 0.5) \times$ IPN with a $R^{2}$ (coefficient of determination) value of 0.95 . 

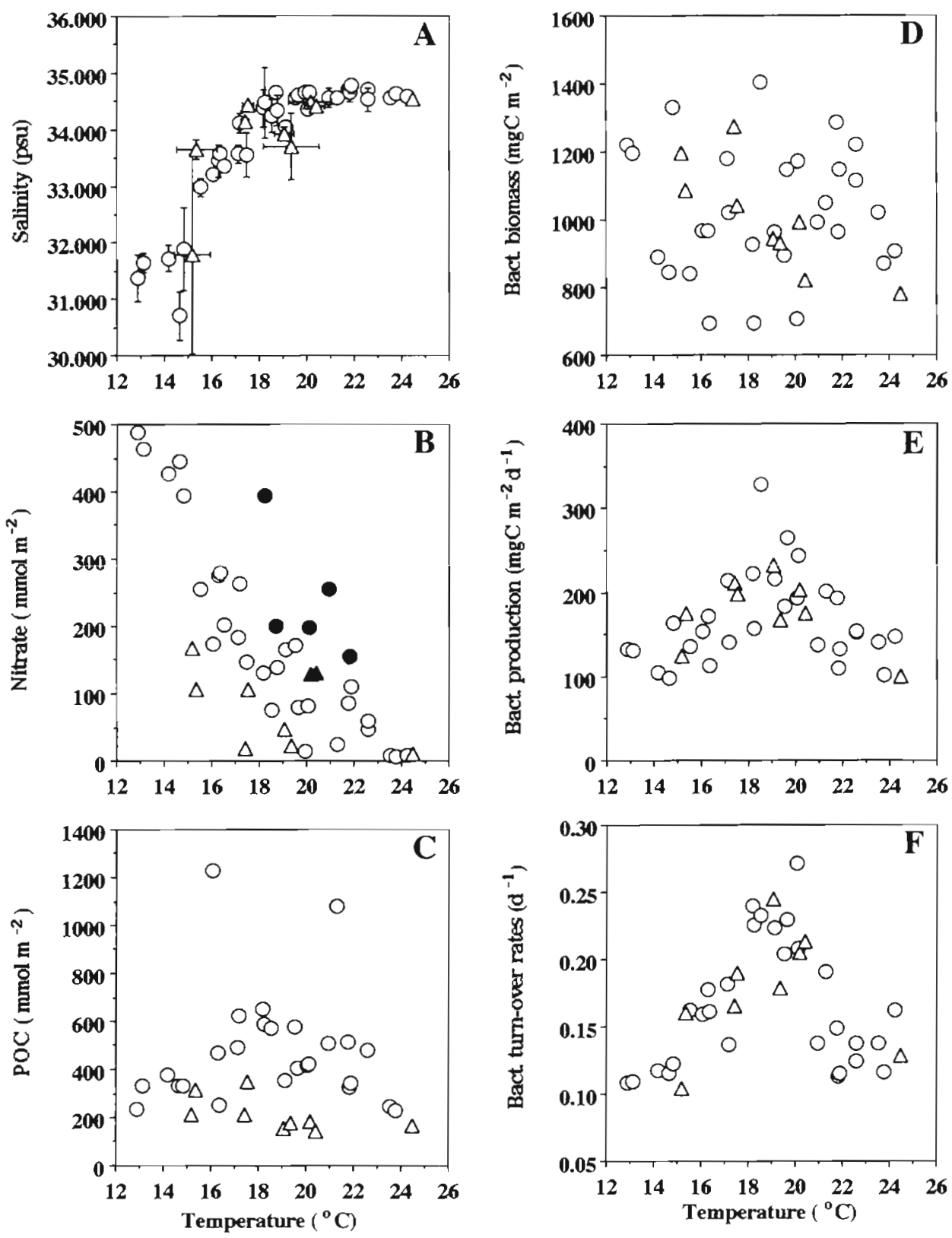

Fig. 2. Scatter plots of the euphotic zone averaged temperature versus averaged salinity (A) and averaged temperature versus other euphotic-zone integrated variables $(\mathrm{B}-\mathrm{F})$. Horizontal or vertical bars in (A) indicate standard deviation. (A) 1996 data; (O) 1997 data. Solid symbols in $(B)$ indicate upwelling stations

Bacterial biomass (BB; 4 to $64 \mathrm{mg} \mathrm{C} \mathrm{m}^{-3}$ ) varied 16 -fold over the study area. Bacterial production (BP) and individual growth rates $\left(\mu ; \mathrm{BP} / \mathrm{BB}_{i}\right.$ Table 1$)$ varied $>40$-fold (0.3 to $\left.147 \mathrm{mgC} \mathrm{m}^{-3} \mathrm{~d}^{-1}\right)$ and > $>$-fold $\left(007\right.$ to $\left.0.37 \mathrm{~d}^{-1}\right)$, respectively. The integrated values of $\mathrm{BB}$ and $\mathrm{BP}$ (IBB and IBP) as well as the averaged growth rates $\left(\mu_{z e}\right.$ IBP/IBB), were in the ranges of 694 to $1406 \mathrm{mg} \mathrm{C} \mathrm{m}^{-2}, 98$ to $328 \mathrm{mg} \mathrm{C} \mathrm{m}^{-2} \mathrm{~d}^{-1}$ and 0.11 to $0.27 \mathrm{~d}^{-1}$, respectively. In 1997, no clear spatial pattern for IBB existed in areas inside the shelf edge. However, in warm water areas $\left(>20^{\circ} \mathrm{C}\right)$, IBB tended to decrease from the shelf edge to the open ocean (Fig. 2D). On the 1996 cruise, IBB decreased from the inner to outer shelf, as indicated by the negative trend between IBB and temperature (Fig. 2D).
On both cruises, in terms of their relationships with temperature, bacterial rate parameters (IBP and $\mu_{z e}$ ) showed similar patterns over the shelf (Fig. $2 E-F$ ). In areas with temperatures $<20^{\circ} \mathrm{C}$. IRP and $\eta_{i \mathrm{e}}$ increased with rising temperature; above $20^{\circ} \mathrm{C}$, these parameters showed no significant trend relative to temperature (see below). The use of the averaged value $\left(\mu_{\mathrm{ze}}\right)$ to represent bacterial individual growth rates at different depths (i.e. $\mu$ ) seems reasonable since the values of $\mu$ did not vary much within the euphotic zone at any given station. For almost all of the sampling stations, the standard deviations of $\mu$ were quite small, while the coefficients of variation ( $\mathrm{CV}=$ standard deviation $x$ $100 /$ average) seldom exceeded $20 \%$. The correlation 
coefficient (i.e. $r$ ) of $\mu$ versus $\mu_{\text {ze }}$ was significant $(r=0.92, n=38, p<0.01$ ).

The relationship of temperature versus IBP (and $\mu_{z e}$ ) was examined with a polynomal curve fitting method, which justified that the apex of that best-fitted curve was located at $20^{\circ} \mathrm{C}\left(\mathrm{n}=38, \mathrm{R}^{2}=0.67, \mathrm{p}<0.01\right)$. After this, the multiple regression of natural log transformed IBP (ln IBP) and $\mu_{z e}\left(\ln \mu_{z e}\right)$ on temperature and IPOC (independent variables) in the ranges of $<20^{\circ} \mathrm{C}$ and $>20^{\circ} \mathrm{C}$ was performed. Inside the shelf edge $\left(<20^{\circ} \mathrm{C}\right)$, more than $50 \%$ of the variations $\left(R^{2}=0.48\right.$ to 0.77 ; $\mathrm{p}<0.01$ ) of IBP and $\mu_{z e}$ could be explained by temperature alone (Table 2); in fact, the slopes of $\ln$ IBP on temperature for the 1996 $(0.10 \pm 0.04)$ and $1997(0.10 \pm 0.02)$ cruises were almost identical (ANCOVA; $p>0.05$ ). Analysis of $\ln \mu_{z e}$ versus temperature showed the same trend with slope values of $0.12 \pm 0.05$ and $0.12 \pm 0.01$, respectively. The estimated $Q_{10}$ (the increase in the growth rate for each $10^{\circ} \mathrm{C}$ increase in temperature) values of IBP and $\mu_{z e}$ for the pooled data set were 2.7 and 3.3 , respectively. Neither temperature nor IPOC correlated with IBB.

Conversely, IBP, $\mu_{z e}$ and IBB values recorded outside the shelf edge were posltively correlated with IPOC, with $R^{2}$ values of 0.37 to $0.78(\mathrm{n}=11, \mathrm{p}<0.01)$. For the $<20^{\circ} \mathrm{C}$ data, the addition of IPOC as an extra independent variable only slightly increased the $R^{2}$ values of IBP and $\mu_{z e}$ (Table 2 ). On the other hand, IPOC was the predominant factor in explaining the variance of IBP, $\mu_{z e}$ and IBB in the warm water areas.
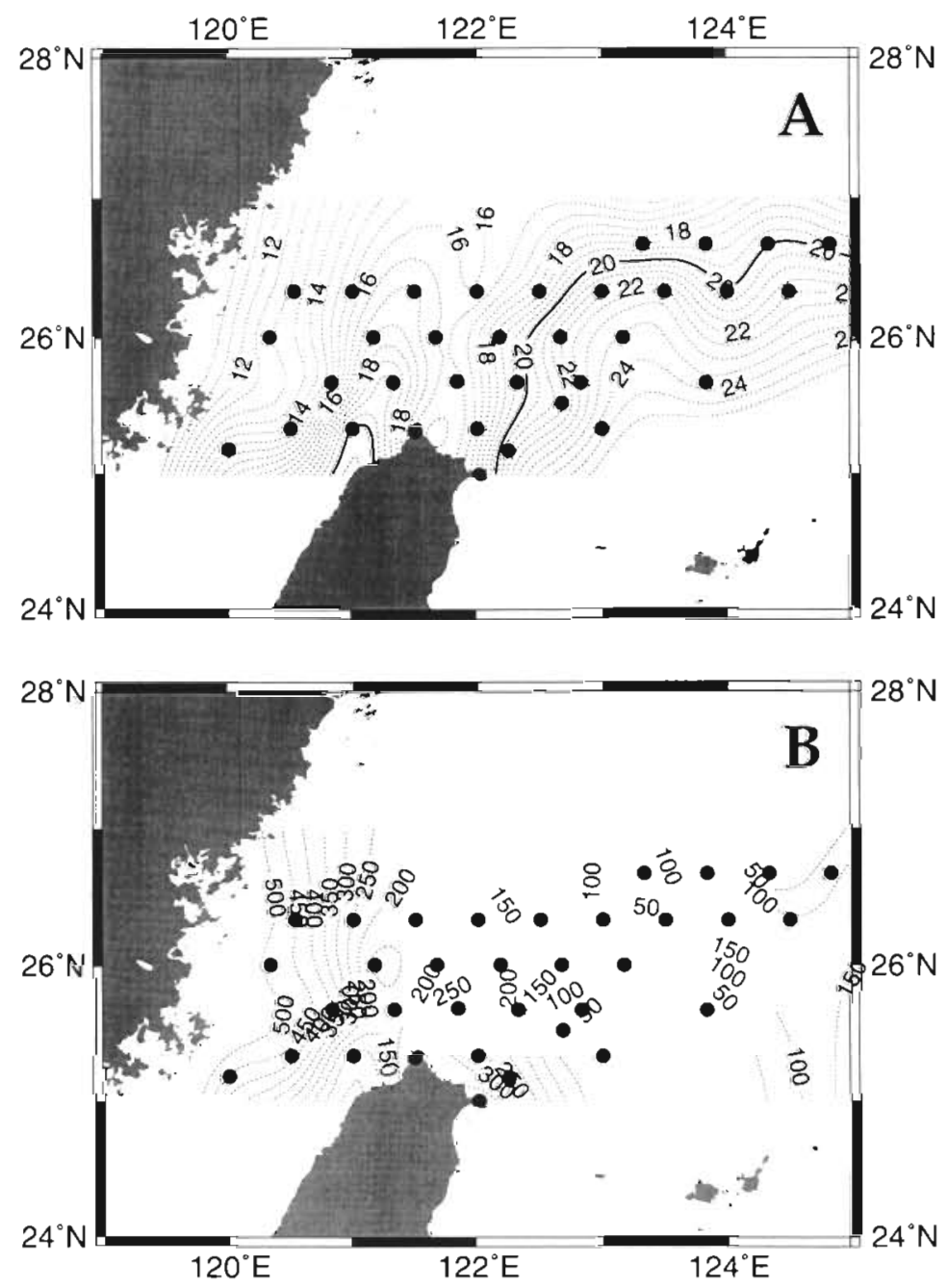

Fig 3 Contours of the euphotıc-zone averaged temperature $\left(A \cdot{ }^{\circ} \mathrm{C}\right)$ and

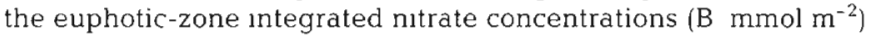

Table 1. Ranges of measured variables collected from the euphotic zone in the continental shelf of the southern East China Sea dunng the spring seasons of 1996 and 1997

\begin{tabular}{|c|c|c|c|c|}
\hline Variables & Symbol & Unit & 1996 & 1997 \\
\hline Temperature & $\mathrm{T}$ & ${ }^{\circ} \mathrm{C}$ & $13.6 / 24.5$ & $12.2 / 24.3$ \\
\hline Salinity & $\mathrm{S}$ & psu & $30.043 / 34.497$ & $30.012 / 35.700$ \\
\hline Nitrate & $\mathrm{NO}_{3}^{-}$ & $\mu \mathrm{M}$ & $<0.2^{\mathrm{d}} / 9.6$ & $<0.2 / 15.6$ \\
\hline $\begin{array}{l}\text { Particulate organic } \\
\text { carbon }\end{array}$ & $\mathrm{POC}$ & $\mu \mathrm{M}$ & $1.2 / 52.2$ & $3.2 / 60.4$ \\
\hline Chlorophyll & Chl & $\mathrm{mg} \operatorname{chl~} \mathrm{m}^{-3}$ & $0.2 / 2.4$ & $0.2 / 4.0$ \\
\hline Bacterial biomass & $\mathrm{BB}$ & $\mathrm{mg} \mathrm{C} \mathrm{m}^{-3}$ & $4 / 64$ & $14 / 35$ \\
\hline Bacterial production & $\mathrm{BP}$ & $m g C m^{-3} d^{-1}$ & $0.3 / 14.7$ & $1.3 / 11.5$ \\
\hline Bacterial turn-over ${ }^{b}$ & $\mu$ & $d^{-1}$ & $0.07 / 0.31$ & $0.07 / 0.38$ \\
\hline \multicolumn{5}{|l|}{ Detection limit } \\
\hline \multicolumn{5}{|l|}{${ }^{b}$ Calculated as $\mathrm{BP} / \mathrm{BB}$} \\
\hline
\end{tabular}

\section{DISCUSSION}

The spatial patterns of temperature over the shelf give rise to 2 important implications in this study. Physiologically, temperature may directly affect bactenal growth rates and thus production. which peaked at $20^{\circ} \mathrm{C}$ (Fig. 2E-F). This confirms many studies (Shiah \& Ducklow 1995 and citations therein) which have indicated that in temperate and subtropical areas, the optimal temperature for bacterial growth was in the range of 20 to $25^{\circ} \mathrm{C}$. From a hydrographic point of view, the $20^{\circ} \mathrm{C}$ isotherm (Fig. 3A) located at the shelf edge served as a mark separating the study area into 2 systems with distinct temperature (cold vs warm) and trophic (mesotrophic vs oligotrophic) characteristics. Temperature 
Table 2. Coefficient of determination $\left(R^{2}\right)$ (all significant at $p<$ 0.01 level) for multiple regression analyses of temperature $(T)$ and the euphotic-zone integrated particulate organic carbon concentrations (IPOC) versus bacterial measurements (the euphotic-zone integrated bacterial production [IBP], bacterial biomass [IBB] and averaged growth rates $\left[\mu_{k ;}\right.$ IBP/IBB] after natural log transformation). $T$, IPOC: independent variables. n: sampling size

\begin{tabular}{|lcccc|}
\hline Category & $\mathrm{n}$ & $\begin{array}{c}\mathrm{R}^{2} \text { for } \\
\text { T only }\end{array}$ & $\begin{array}{c}\mathrm{R}^{2} \text { for } \\
\text { IPOC only }\end{array}$ & $\begin{array}{c}\mathrm{R}^{2} \text { for } \\
\mathrm{T}+\mathrm{IPOC}\end{array}$ \\
\hline$<\mathbf{2 0 ^ { \circ } \mathrm { C }}$ & & & & \\
$\ln \mathrm{IBP}$ & 27 & 0.48 & - & 0.48 \\
$\ln \mu_{z e}$ & 27 & 0.77 & - & 0.79 \\
$\ln \mathrm{IBB}$ & 27 & - & - & - \\
& & & & \\
$>\mathbf{2 0} \mathbf{0}^{\circ} \mathrm{C}$ & 11 & - & 0.78 & 0.79 \\
$\ln \mathrm{IBP}$ & 11 & - & 0.37 & 0.37 \\
$\ln \mu_{2 \mathrm{e}}$ & 11 & - & 0.52 & 0.53 \\
$\ln \mathrm{IBB}$ & & & & \\
\hline
\end{tabular}

was an indication of the inorganic nutrient supply (Figs. 2B \& 3B) which, in turn, affected algal biomass, activity (i.e. primary production) and, hence, the potential supply rates of substrate (IPOC; see below) required for bacterial growth. This might be particularly true for bacteria outside the shelf edge in warm and oligotrophic waters (Fig. $2 \mathrm{C}$ ). Since bacterial rate parameters peaked at $20^{\circ} \mathrm{C}$ and the $20^{\circ} \mathrm{C}$ isotherm roughly separated the study area into 2 different trophic systems, we chose the temperature of $20^{\circ} \mathrm{C}$ as the cut-off point in statistical analyses.

Primary production and dissolved organic carbon concentration data were not available in this study. IPOC was used as the index of substrate supply since they were positively correlated with Ichl. In fact, IPOC might be more indicative than Ichl since all biological components (except most bacteria and viruses), dead or alive, are included.

The results here suggest that the controlling mechanisms of bacterial growth might be quite different inside and outside the shelf edge, as judged from their distinct relationships with temperature and IPOC in different temperature ranges $\left(<20^{\circ} \mathrm{C}\right.$ and $>20^{\circ} \mathrm{C}$; Fig. 2F, Table 2). More specifically, it is hypothesized here that during the spring season, hacterial growth inside and outside the shelf edge are primarily controlled by temperature and substrate supply, respectively.

Substrate supply has long been recognized as a dominant factor in regulating bacterial growth rates in aquatic ecosystems (Cole et al. 1988, see also Ducklow \& Carlson 1992, Fuhrman 1992 for review). However, several recent studies have suggested that the strength of bottom-up control might be system dependent and might also change temporally within a system. Duck- low \& Shiah (1993) first proposed that bacterial growth in estuaries might be temperature limited, with the substrate supply playing a less important role. This hypothesis has been confirmed by experiments performed in Delaware Bay (Hoch \& Kirchman 1993), Chesapeake Bay (Shiah \& Ducklow 1994b, 1995) and Kiel Fjord (Berman et al. 1994). These findings are of little surprise because many estuaries are eutrophic, showing large amounts of external inputs, either in terms of inorganic nutrients or organic substrate. Under such conditions, bacterial growth might actually be saturated by high substrate supply rates during most seasons of the year.

The data in this study lend support to the fact that the temperature dominance hypotheses could also be applied in explaining the spatial pattern of bacterial growth rates in a mesotrophic environment. As argued by Ducklow \& Shiah (1993) and others, if bacterial growth is primarily controlled by factors other than temperature, then a strong relationship between bacterial growth rates and temperature is less likely to occur. That is, bacteria simply cannot grow without the proper amount of substrate supply, even when growth temperature is optimal (see also below). More importantly, the $Q_{10}$ value derived from this study (3.3) was very similar to the ones reported by Shiah \& Ducklow (1994a, 1995) in their seasonal studies in Chesapeake Bay (averaged $Q_{10}=3.2$ ) and in a salt marsh tidal creek (overall $Q_{10}=3.2$ ). White et al. (1991) reported an average $Q_{10}$ value of 3.3 for bacterial growth rates based on data collected from 57 studies conducted in fresh, marine and estuarine/coastal waters. Interestingly, those 3 studies addressed the temperature effects on bacterial temporal variability within eutrophic systems, whereas the present one emphasized spatial variability in mesotrophic environment (i.e. areas inside the shelf break). This indicates that the temperature dependence of bacterial growth rates $\left(Q_{10}\right)$ might be comparable in both systems and over both temporal and spatial scales.

In warm water areas, a strong correlation between bacterial growth rates and IPOC (Table 2) was observed. This indicates that substrate supply rates rather than temperature might be the major factor in regulating hacterial grnwth rates in areas outside the shelf edge. The following scenario is proposed as an explanation. In areas next to the oligotrophic environment (the $\mathrm{KW}$ ), temperature $\left(20.0\right.$ to $\left.24.5^{\circ} \mathrm{C}\right)$ itself was probably optimal for bacterial growth (Shiah \& Ducklow 1994a,b, 1995). However, as temperature increased, the system became more oligotrophic (Fig. 2B) which resulted in the reduction of substrate supply and thus bacterial growth rates. This implies that as the system became more of an oligotrophic condition, the more significant substrate control of bacter- 
ial growth might become. Outside the shelf edge, IBB was positively correlated with IPOC with an $\mathrm{R}^{2}$ value of 0.52 . This observation supported the conclusion of Sanders et al. (1992) who suggested that bottom-up (substrate supply) control dominated in regulating bacterial biomass in oligotrophic environments

In addition to temperature and substrate supply rate, other factors, such as bacterivory and viral lysis (topdown control; see Ducklow \& Carlson 1992, Fuhrman 1992 for review) also play significant roles in regulating bacterial biomass and production. Bacterial biomass inside the shelf edge showed no distinct relationships with any other environmental variables. It is very possible that the spatial pattern of bacterial biomass inside the inner shelf was more affected by these 2 processes. However, no tangible conclusion regarding this can be made due to the lack of bacterivory and viral lysis data.

The outcrop of the nutrient-enriched Kuroshio Subsurface Waters (KSW) caused by the change of bottom topography definitely has a strong influence on the hydrography and thus, the spatial patterns of biological phenomena. The most recent study (Liu et al. 1999) showed that for the continental shelf of the ECS, nutrient (nitrate as example) flux derived from the KSW $(5.5$ to $7.1 \mathrm{kmol} \mathrm{N} \mathrm{s}^{-1}$ ) at the shelf edge adjacent northern Taiwan (i.e. the first INO anomaly in Fig. 3B) was at least 2 -fold higher than that from coastal input (i.e. river runoffs; $2.1 \mathrm{kmol} \mathrm{N} \mathrm{s}^{-1}$; Zhang 1996). Our observation suggests that there might be other upwellings (i.e. the second INO anomaly in Fig. 3B) along the shelf edge. Their occurrence frequency (persistent or episodic) and possible contribution in importing nutrients into the continental shelf of the ECS and the oligotrophic Kuroshio waters merit further investigation.

Another interesting phenomenon which is worthy of further study is that the values of IPOC were also more or less peaked at the boundary of the inner and outer shelf regions (ca 16 to $20^{\circ} \mathrm{C}$; Fig. 2C). The high correlation observed between Ichl and IPOC (see above) indicated that the biomass (and perhaps activities) of algae and other planktoners within this 'transition zone' were high. In comparison to this area, nutrient-rich waters in the inner shelf (see also below) were colder and more turbid, which were not favorable for the development of high Ichl and IPOC (Shiah et al. 1996). More interestingly, the nitrogen to phosphate ratios (N/P ratios) from the river runoffs were in the range of 46 to 84 (Edmond et al. 1985, Zhang 1996), while the N/P ratios of the KSW (14.0 to 15.4 ; Liu et al. 1999) were slightly lower than the Redfield ratio of 16 . Wong et al. (1998) deduced that such serious N/P imbalance probably was the major factor in limiting algal biomass (and productivity) in the inner shelf areas. Finally, differential grazing pressure from zooplankton might be an important reason but needs to be verified in the future.
During spring, the spatial variation of bacterial growth rates and production in the continental shelf of the East China Sea were interactively regulated by both temperature and substrate supply. However, the relative strength of these 2 controlling factors varied, with temperature and substrate supply dominating inside and outside the shelf edge, respectively. The strong relationship observed between bacterial growth rates and temperature implies that during spring, bacterial growth in the shelf system might not be limited by substrate supply. In view of other published results derived from the eutrophic environment, it seems feasible that in both mesotrophic and eutrophic ecosystems, temperature plays a more dominant role than substrate supply in regulating bacterial growth rates, at least during certain seasons (e.g. spring) of the year. In addition, similar $Q_{10}$ values derived from this and other studies further suggest that temperature dependence of bacterial growth and production might be comparable in these ecosystems.

Acknowledgements. CORE-NSC contribution paper number 7. Support for this research was provided by the National Science Council (NSC), Taiwan, ROC. Valuable comments from Dr J. Christian and 2 anonymous reviewers on this manuscript are deeply appreciated. We thank the officers and crew members of the RV 'Ocean Researcher I' for cruise assistance.

\section{LITERATURE CITED}

Berman T, Hoppe H, Gocke K (1994) Response of aquatic bacterial populations to substrate enrichment. Mar Ecol Prog Ser 104:173-184

Biscaye PE, Flagg CN, Falkowski PG (1994) The shelf-edge exchanges processes experiment, SEEP-II: an introduction to hypotheses, results and conclusions. Deep-Sea Res Part II $41(2 / 3): 231-252$

Cho BC, Azam F (1988) Major role of bacteria in biogeochemical fluxes in the ocean's interior. Nature 332:441-443

Cole JJ, Findlay S, Pace ML (1988) Bacterial production in fresh and saltwater ecosystems: a cross-system overview. Mar Ecol Prog Ser 43:1-10

Ducklow HW, Carlson CA (1992) Oceanic bacterial production. In: Marshall KC (ed) Advance in microbial ecology. Plenum, New York, p 113-181

Ducklow HW, Shiah FK (1993) Bacterial production in estuaries. In: Ford $T$ (ed) Aquatic microbiology: an ecological approach. Blackwell Sci Publ, Boston, p 261-287

Edmond JM, Spivack A, Grant BC, Hu MH, Chen Z, Chen S, Zeng $X$ (1985) Chemical dynamics of the Changjiang estuary. Cont Shelf Res 4:17-36

Fuhrman JA (1992) Bacterioplankton roles in cycling of organic matter: the microbial food web. In: Falkowski PG, Woodhead AD (eds) Primary productivity and biogeochemical cycles in the sea. Plenum, New York, p 361-383

Fuhrman JA, Azam F (1982) Thymidine incorporation as a measurement of heterotrophic bacterioplankton production in marine surface waters: evaluation and field results. Mar Biol 66:109-120 
Gong GC, Liu KK, Pai SC (1995) Prediction of nitrate concentration from two end member mixing in the southern East China sea. Cont Shelf Res 15:827-842

Gong G, Shiah F, Liu K, Chuang W, Chang J (1996) Eftect of Kuroshio intrusion on the chlorophyll distribution in the southern East China sea north of Taiwan during spring, 1993. Cont Shelf Res 17(1):79-94

Griffith P, Shiah F, Gloersen $K$, Ducklow HW, Fletcher M (1994) Activity and distribution of attached bacteria in Chesapeake Bay. Mar Ecol Prog Ser 108:1-10

Hobbie JE, Daley RJ, Jasper S (1977) Use of nuclepore filters for counting bacteria by fluorescence microscopy. Appl Environ Microbiol 33 (5):1225-1228

Hoch MP, Kirchman DL (1993) Seasonal and inter-annual variability in bacterial production and biomass in a temperate estuary. Mar Ecol Prog Ser 98:283-295

Kemp PF (1994) Microbial carbon utilization on the continental shelf and slope during the SEEP-II experiment. DeepSea Res Part II 41(2/3):563-582

Lancelot C, Billen G (1984) Activity of heterotrophic bacteria and its coupling to primary production during the spring phytoplankton bloom in the South Bight of the North Sea. Limnol Oceanogr 29(4):721-730

Levitus S (1982) Climatological atlas of the world ocean. NOAA, Seattle

Liu K, Gong G, Shyu C, Pai S, Wei C, Chao S (1992) Response of Kuroshio upwelling to the onset of northeast monsoon in the sea north of Taiwan: observations and a numerical simulation. J Geophys Res 97:12511-12526

Liu KK, Tang TY, Gong GC, Chen LY, Shiah FK (1999) Crossshelf and along-shelf nutrient fluxes from flow fields and chemical hygrography observed in the southern East China Sea off northern Taiwan. Cont Shelf Res (in press)

Editorial responsibility: Farooq Azam,

La Jolla, California, USA
Mantoura RFC, Martin JM, Wollast R (1991) Ocean margin processes in global change. Wiley \& Sons, New York

Parsons TR, Maita Y, Lalli CM (1984) A manual of chemical and biological methods for seawater analysis. Pergamon, New York

Sanders RW, Caron DA, Berninger U (1992) Relationships between bacteria and heterotrophic nanoplankton in marine and fresh waters: an inter-ecosystem comparison Mar Ecol Prog Ser 86:1-14

Shiah F, Ducklow HW (1994a) Temperature and substrate regulation of bacterial abundance, production and specific growth rate in Chesapeake Bay, USA. Mar Ecol Prog Ser 103:297-308

Shiah F, Ducklow HW (1994b) Temperature regulation of heterotrophic bacterioplankton abundance, production, and specific growth rate in Chesapeake Bay. Limnol Oceanogr 39(6): 1243-1258

Shiah F, Ducklow HW (1995) Multi-scale variability in bacterioplankton abundance, production and specific growth rate in a temperate salt marsh tidal creek. Limnol Oceanogr 40(1):55-66

Shiah F: Gong $\mathrm{G}$, Liu K (1996) Light effects on phytoplankton photosynthetic performance in the southern East China Sea north of Taiwan. Bot Bull Acad Sin 37:133-140

Wong GTF, Gong GC, Liu KK, Pai SC (1998) 'Excess nitrate' in the East China Sea. Estuar Coast Shelf Sci (in press)

White PA, Kalff J, Rasmussen JB, Gasol JM (1991) The effects of temperature and algal biomass on bacterial production and specific growth rate in freshwater and marine habitats. Microb Ecol 21:99-118

Zhang J (1996) Nutrient elements in large Chinese estuaries Cont Shelf Res 16:1023-1045

Submitted: February 9, 1998; Accepted: August 31, 1998 Proofs received from author(s): May 26, 1999 